\title{
Research on the Construction of Informatization Teaching Mode in Colleges and Universities under the Background of Big Data
}

\author{
Zhiqiang Hong \\ Department of Human and Art \\ Hainan College of Economics and Business \\ Haikou, Hainan
}

\author{
Chunyi Li \\ Department of International Education \\ Hainan College of Economics and Business \\ Haikou, Hainan
}

\begin{abstract}
In recent years, Chinese colleges and universities have continuously strengthened the construction and reform of information-based teaching modes. With the rapid development of big data technology, the construction of new teaching methods constitutes the basis of informatizaiton teaching in universities. In this paper, the connotation and characteristics of big data as well as the practical problems in current informatizaiton teaching in colleges and universities are analyzed, moreover, the construction modes and paths of the informatization teaching of the universities in the age of big data are also studied.
\end{abstract}

Keywords-Informatization teaching; Construction mode; Big data; Colleges and universities

\section{INTRODUCTION}

Under the guidance of the Guidelines for the Development of the Ten Years of Education Informatization Program (20112020), the construction of higher education informatization teaching in China has continued to develop in teaching, research and management in universities, the application of information technology in teaching has become a hot topic for scholars [1-2]. The influence and changes of information technology renewal and development on traditional classrooms have become an important research direction. In the era of big data, "Internet + " education has attracted scholars' extensive discussion. The reform of education model is an important factor in improving the quality of education in the future. How to reform the education model requires more data analysis and continuous summary of experience and ideas. All these need to be analyzed by big data. Big data plays an important supporting role in improving the quality of education, promoting education fairness, and reforming educational methods. With the impact of big data on education, the information-based teaching model has gradually attracted the attention of scholars.
The purpose of using informatization teaching model is to cultivate innovative talents. The use of informatization technology for life-long learning is a requirement for future learners in the era of big data. The teaching model at present is difficult to meet the requirements in cultivating innovative talents [3-4]. It is urgent to change and build an informationbased teaching model. Judging from the evolution track and development context of the development of education informatization model at home and abroad, in the age of big data, the informatization in higher education institutions has shifted from the original software and platform services to the new data service model. With the application of microcurriculum, MOOC, and flipped classroom, massive amounts of data have been produced. The effective application of big data analysis techniques to integrate higher education teaching and information technology has become an important issue for domestic and foreign scholars. The research on the construction of university information teaching model has important theoretical value and practical significance under the background of big data.

\section{THE MAJOR PROBLEMS EXISTING IN THE INFORMATIZATION TEACHING MODEL OF CHINESE UNIVERSITIES IN THE BACKGROUND OF BIG DATA}

China's higher education informatization has experienced nearly 20 years of development, from the stage of developing infrastructure construction in the late 1990s to the stage of Indepth development of information technology in higher education in teaching practice, scientific research, and teaching management [5]. However, with regard to the current status of information construction in colleges and universities, whether it is the construction of teaching models, the transformation of teaching objectives, the innovation of teaching contents or the comprehensiveness of the evaluation, did not achieve a great breakthrough. Problems mainly lies in the following aspects: traditional teaching is still the main teaching mode; teachers in the classroom unilaterally pass on teaching information to students; teaching objectives are still completed in accordance with a unified syllabus; teaching content is still based on teaching discord as a blueprint for single transmission and ignore complete and comprehensive teaching evaluation. 


\section{A. Lacking Innovation with Simple Goals}

Currently, various universities and colleges have carried out different models of information-based teaching in different degrees, mainly in the modes of practical operation, scenario simulation and investigation. Many colleges and universities only transfer the teaching process from traditional classrooms to new multimedia classrooms with modern information-based teaching equipment. The teaching content and teaching methods have not changed much. Teachers still give priority to teaching. Although under the existing model, communication between teachers and students can still be completed. Under the supervision of teachers, students can complete their studies and teaching activities are conducted under the requirements of training programs. The teaching effect is obvious, the promotion is fast, the teaching activities are very orderly and the development is smooth. However, due to the limitation of educational resources, the existing teaching models cannot fully reflect the subjective initiative of students' learning and limit the cultivation of innovative abilities. There is a serious homogeneity in the cultivation of talents in colleges and universities.

\section{B. Simple Evaluation Mechanism for Educational Effectiveness}

The existing teaching structure is still teacher-centered, and the evaluation criteria for students' learning effects are simplified and modeled. The current information-based teaching cannot adapt to student's individual learning needs and cannot truly focus on students. The school's awareness of education services needs to be improved. The main subject of the evaluation of educational effectiveness is the teacher. The forms of evaluation are based on tests of subjects to examine students' understanding and mastery of knowledge, it emphasizes the final learning results with simple evaluate methods and evaluation contents. What $s$ more, the evaluation mechanism is seriously simple, lacking of personalization and diversification. And it relies too much on subjective experience for judgment and evaluation.

\section{Deeply-rooted Traditional Education Concept}

Most teachers teach according to their own preparations, and are reluctant to carry out in-depth research on the subjectbased teaching philosophy based on information technology, but only use multimedia and production of CAI courseware as an embodiment of information-based teaching methods. Many practical teaching activities conducted in informational classrooms are also in a formal form. There is no targeted design of teaching content and teaching methods, and it is impossible to achieve the goals of laying sound foundation on student's subject philosophy, broadening the frontier horizon of subject development, and developing students' academic innovation spirit. Students are also accustomed to accept knowledge passively, so that the final exam is a short-term learning goal and it is impossible to carry out long-term study. It is easy to accomplish teaching with such a teaching model, however, there is a lack of stimulation strategies to arousing students' interest and initiative. As a result, it becomes more and more difficult for students to improve their initiative to gain knowledge.

\section{Serious Phenomenon of "High-tech, low-efficiency"}

Although universities are currently conducting information-based teaching, the investment in the informationbased teaching model is very high, and a large number of learning centers and experimental teaching centers have been established. However, due to hardware and software issues and problems of maintenance and management, the investment makes small contribution to students' learning effects. The practicality of the information-based teaching environment needs to be improved, and the quality needs to be improved.

At present, China's educational resources MOOC is largely open, and projects and mutual recognition programs for credit certification have been introduced. Although the registration volume is large, the proportion of students who can truly complete the course requirements and successfully pass the examination is not high.

\section{THE CONSTRUCTION OF UNIVERSITY INFORMATIZATION TEACHING MODELS}

\section{A. To Adhere to the Basic Idea of Big Data Drive}

The informatization teaching model based on big data is a brand-new teaching model. Its establishment and application are all very complicated projects, requiring teachers, schools, and all levels of the country to adhere to big data. This concept continues to promote the development of this new teaching model. From the perspective of teachers, information technology is only a tool for teachers' teaching. Teachers should not be busy serving information technology and should not change from human irrigation to machine irrigation. Otherwise, information technology will be meaningless. At the same time, to make something good, we must first sharpen its tools. If teachers want to make good use of informatization teaching, they must master the operation of related software. Therefore, teachers should innovate their educational concepts, adhere to the "digital teaching" method, use data-driven teaching to establish goals of personalized talent cultivation based on big data.

As for school, teaching software development should follow the concept of being various, rapid, good and frugal. To be various means more functions and resources; to be rapid means to learn and use quickly; to be good is to be human, dynamic; to be frugal is to save money and time.

Therefore, education management personnel must be able to explore teaching methods and projects useful for improving students' learning ability and effectiveness by analyzing a large number of relevant data. What' s more, they can also develop corresponding software for promotion and application. From the perspective of a country, the government should regard the concept of "information technology has a revolutionary impact on the development of education" as a major strategic decision and formulate practical educational policies and regulations in accordance with the education development with the support of big data analysis technology. 


\section{B. To Supports Personalized Education with Big Data}

Big data technology has brought about changes in the information environment of the learning environment. It continuously improve students'learning through feedback, prediction and personalization to satisfy students' information needs for learning, to change their learning methods. Student' s learning process is no longer passive but requires personalized and customized services of highly collaborative. we can get students' learning process data and effect data to reflect the individual's learning process and learning paths through their homework, discussion, experimental records and other data in flipping classroom and MOOC, to analyze and find out more data information to provide environmental support for students' personalized study.

Information resources are the basis of informatization services. Information services collect and analyze a large amount of data information to provide related information services and information products ultimately by using various technologies and methods. In the context of big data, both learning and learning process can continue without fixed textbooks and process. Personalized services are needed. With a large amount of learning resources, it is necessary to provide reasonable and feasible supporting information services to effectively integrate massive amounts of learning information resources, to facilitate the circulation and application of resources. In addition to the hardware equipment that can carry out multimedia teaching such as video equipment, audio equipment, and computers, the reform of information technology in colleges and universities must also guarantee the stability of the network that covers the entire campus. Students can learn online by using tablets and mobile phones at any time and anywhere, with clear and smooth learning videos. In the informatizaiton teaching environment, another important issue is how to help students quickly find the necessary learning resources among a large number of learning resources to provide them with appropriate information. It is common for students to search for resources, but a more effective method is to push information to students in a targeted manner. This "resource search" method can effectively explore effective information from a large number of educational data sources and provide personalized education to meet the needs of students [6].

\section{To Build an Informatization Teaching Environment}

Bloom's theory of learning needs divides knowledge learning into concepts, understandings, and combination. In different stages, informatization teaching should provide students with different types of knowledge. On the premise of ensuring the truthfulness of the source of information, largescale online open courses (MOOC) can be conducted, and an information-based teaching environment can be constructed to integrate traditional centralized teaching with open online courses effectively and give full play to the role of online teaching. MOOC will record the student's learning process and learning content and monitor the entire learning process. Under such learning conditions, students of the beginner will be provided well-structured, basic knowledge. As the learning process progresses, the knowledge will be clustered and the association between the knowledge will be sought and visualized. MOOC will meet the different needs of students, develop different targeted teaching plans for different individuals, give full play to the subjective initiative of students' learning, improve students' self-learning abilities, meet the learning needs of students at different levels of knowledge and finish study according to the learning schedule.

At the same time, MOOC can launch learning communities among students with the same learning interests to promote the evolution and added value of knowledge. The feature of zero copying cost makes the more the digital resources are utilized, the more fully their value is exerted. With the increase of users, digital resources that have already been built can automatically realize their value-added benefits without requiring additional investment. Therefore, we must constantly improve the reform of the teaching system, increase the content of the online question bank and the teacher's teaching, and also record carefully the students' learning information. At present, our country's college MOOC platform has provided a lot of excellent curriculum teaching resources. Teachers from nearly 1,000 colleges and universities across the country have introduced video teaching classes. We must make full use of high-quality resources from key universities to achieve cross-school learning exchanges and promote students' Self-construction of knowledge system.

\section{To Improve University Teachers' Abilities to Analyze the Data}

In the era of big data, teachers are the organizers of information-based teaching. Excellent teachers who are important resources for higher education should constantly update their views on teaching, strengthen their own information application technology level and improve teaching effectiveness. The ability to constantly improve teaching methods and data mining analysis is a new demand on teachers under the background of big data. As a main medium between knowledge and students, teachers should become the leaders for students, not just to be teachers. Teachers should be able to apply informatization teaching to further integrate educational resources through the cloud platform and change teaching methods. They are supposed to use group collaboration teaching methods to help students learn knowledge through online video resources, master the thinking mode of students from top universities, improve their abilities to solve problems. In theory teaching, teachers can adopt new teaching methods like flipped classroom to help students use video resources with less class time. With task learning, theory, practice, and work are integrated, which is also the focus of college students' cultivation in the data background.

Under the background of big data, the construction of university informatization teaching model is a very complicated system and is affected by various factors. The discussion of its construction method should keep pace with the times. The Concept of Big Data used to promote university's informatization teaching is a need to the development of higher education and is the only way for higher education informatization reform. 


\section{THE APPLICATION EFFECT AND ENLIGHTENMENT OF} UNIVERSITY INFORMATION TEACHING BASED ON BIG DATA

The author conducted an interview with the teachers and students from the university he works by using the questionnaire designed by Gretchen lower1son. $\mathrm{He}$ summarized the application experience, learning strategies, teaching methods and information technology applications. Totally there were 60 students participating in the interview, 30 are male students and 30 are female, ranging from freshmen to graduate students. 36 teachers, including lecturers, associate professors, and professors were interviewed.

\section{A. About Learning Experience}

The purpose of this part is to investigate the communication between teachers and students, between students and students, and the effect of student's self-learning. The results show that the interaction of different courses is different. In general, the interaction needs to be strengthened. The students' interactive and self-directed learning has been greatly improved, but teachers mainly focus on teaching and there is a lack of discussion and interaction.

\section{B. About Learning Strategies}

Part of the students are more enthusiastic about selflearning. They are more reluctant to listen to too much explanation from the teachers while the other part of the students depend on teacher's teaching. It is a sharp contrast.

\section{About Teaching Method}

From student feedback, we learned that the quality of the course cases is directly related to the improvement of the teaching effect. The closer the case is to life, the more it stimulates students' curiosity, enabling students to remember more profoundly. However, for basic theoretical courses, how to carry out inquiry teaching is also worth considering.

\section{About the Application of Information Technology}

As can be seen from the questionnaire, students are welcome to apply information technology in the classroom, and it is necessary to apply information technology in teaching. Teachers say yes to the application of information technology but still insist that information technology is not the main factor, course design is still the key.

Through the above analysis, students are more enthusiastic about the application of information technology and are also conscious of the convenience provided by information technology. However, in-depth exploration of classroom teaching can find that the lack of interaction is still obvious. Therefore, the premise of giving full play to the value of information technology in teaching is to give students more room for free exercises, and to design student-centered teaching.

\section{CONCLUSION}

In fact, students are crazy about the application of information technology. They are conscious of the convenience given by information technology for their learning. However, we can still find some deficiency of interactivity when we are teaching. Therefore, more space to help students play freely should be given to students and teaching design should be student-centered, this is the premise of giving full play of the value of information technology.

\section{Acknowledgement}

In this paper, the research was sponsored by Hainan Provincial Education and Teaching Reform Project (Hnjg2016ZD-25).

\section{REFERENCES}

[1] Jiang Youjun. Higher vocational English autonomous design learning in information-based teaching environment $[\mathrm{J}]$. Journal of Science and Technology Information,2012,4:76-77

[2] Liu Ruina. Higher vocational English teachers information teaching team construction path analysis [J]. Journal of Xiangyang Vocational and Technical College, 2014,20:180-181

[3] Wu Binyu. MOOC exploration and application in higher vocational English informatization teaching [J]. Journal of Nanning Vocational and Technical College,2015,01:60-62

[4] Zhou Yongxiang. The application of micro in higher vocational English informatization teaching] J]. Journal of Chongqing Electronic Engineering Vocational College,2015,119:119-12

[5] Zhao H M, Dong-Ni W U, Zhou Z M, et al. Research on the teaching reform of information Courses Based on Flipped Classroom under the Background of Big Data- A Case Study of "Signal and System" [J]. Computer Knowledge \& Technology,2016,(34):205-207

[6] Jin Ling. Big Data and Informatization Teaching Reform [J].Journal of China Electronic Education, 2013(321):8-13 